Prepared in cooperation with the New York State Department of Environmental Conservation

Overview and Methodology for a Study To Identify Fecal Contamination Sources Using Microbial Source Tracking in Seven Embayments on Long Island, New York

Scientific Investigations Report 2021-5033 
Cover. Swan River in Patchogue, New York, viewed looking north from a dock during a sampling trip; photograph by Tristen Tagliaferri, U.S. Geological Survey. 


\section{Overview and Methodology for a Study To Identify Fecal Contamination Sources Using Microbial Source Tracking in Seven Embayments on Long Island, New York}

By Tristen N. Tagliaferri, Shawn C. Fisher, Christopher M. Kephart, Natalie Cheung, Ariel P. Reed, and Robert J. Welk

Prepared in cooperation with the

New York State Department of Environmental Conservation

Scientific Investigations Report 2021-5033 


\section{U.S. Geological Survey, Reston, Virginia: 2021}

For more information on the USGS - the Federal source for science about the Earth, its natural and living resources, natural hazards, and the environment—visit https://www.usgs.gov or call 1-888-ASK-USGS.

For an overview of USGS information products, including maps, imagery, and publications, visit https://store.usgs.gov/.

Any use of trade, firm, or product names is for descriptive purposes only and does not imply endorsement by the U.S. Government.

Although this information product, for the most part, is in the public domain, it also may contain copyrighted material and images protected by publicity rights. Use of photographs or images may require permission to reproduce copyrighted items or the likeness of a person. Permission must be secured from the copyright owner or person whose likeness is being used. For more information, visit https://usgs.gov/copyright.

Suggested citation:

Tagliaferri, T.N., Fisher, S.C., Kephart, C.M., Cheung, N., Reed, A.P., and Welk, R.J., 2021, Overview and methodology for a study to identify fecal contamination sources using microbial source tracking in seven embayments on Long Island, New York: U.S. Geological Survey Scientific Investigations Report 2021-5033, 8 p., https://doi.org/10.3133/ sir20215033.

ISSN 2328-0328 (online) 


\title{
Contents
}

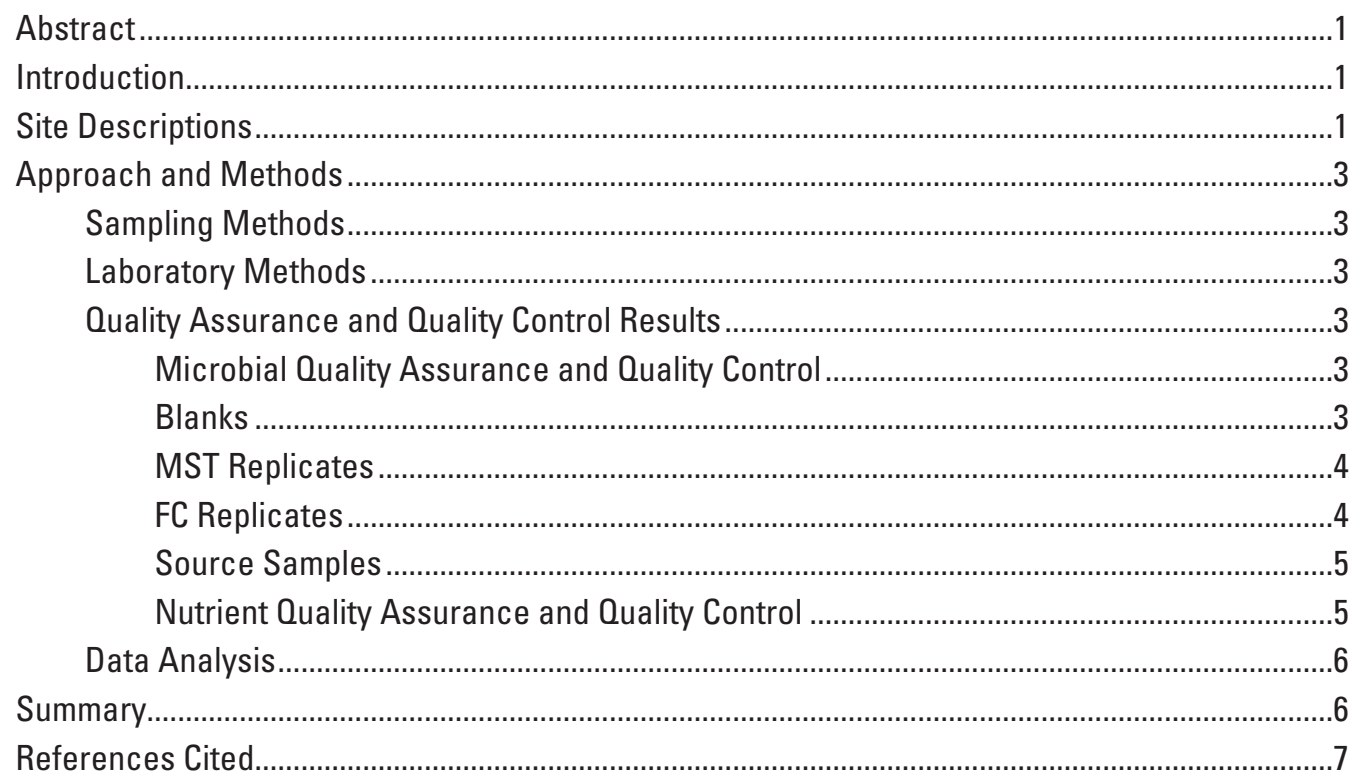

\section{Figure}

1. Map showing seven embayments on Long Island, New York, where microbial source tracking was used to determine sources of fecal contamination .2

\section{Tables}

1. Sample results for quality-assurance blank samples collected at seven embayments on Long Island, New York, from 2018 to 2019.

2. Average reported values of Bacteroides and Helicobacter markers from sources studied on Long Island, New York, for microbial source tracking

3. Results from blank samples collected from 2017 to 2019 for various nutrient analyses .

$$
3
$$
3 . 5 ? 7

\author{
1
}

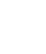

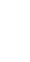

,
. 


\section{Abbreviations}

$\begin{array}{ll}\text { AVLD } & \text { absolute value log-10 difference } \\ \text { BacCan } & \text { canine-associated Bacteroides marker } \\ \text { DEC } & \text { New York State Department of Environmental Conservation } \\ \text { DNA } & \text { deoxyribonucleic acid } \\ \text { FC } & \text { fecal coliform bacteria } \\ \text { GFD } & \text { waterfowl-associated Helicobacter marker } \\ \text { GIS } & \text { geographic information system } \\ \text { HF183 } & \text { human-associated Bacteroides marker } \\ \text { MPN } & \text { most probable number } \\ \text { MRL } & \text { minimum reporting limit } \\ \text { MST } & \text { microbial source tracking } \\ \text { NWIS } & \text { National Water Information System } \\ \text { PEHL } & \text { Public Environmental Health Laboratory } \\ \text { Rum2Bac } & \text { ruminant-associated Bacteroides marker } \\ \text { USGS } & \text { U.S. Geological Survey }\end{array}$




\title{
Overview and Methodology for a Study To Identify Fecal Contamination Sources Using Microbial Source Tracking in Seven Embayments on Long Island, New York
}

\author{
By Tristen N. Tagliaferri, Shawn C. Fisher, Christopher M. Kephart, Natalie Cheung, Ariel P. Reed, and \\ Robert J. Welk
}

\begin{abstract}
Between June 2018 and July 2019, the U.S. Geological Survey collaborated with the New York State Department of Environmental Conservation to analyze water quality in seven embayments on Long Island, New York, for a study to examine fecal contamination using microbial source tracking. This report documents the approach, methodology, and qualityassurance data used in the study. All samples and field data were collected in accordance with U.S. Geological Survey National Field Manual procedures. Samples were analyzed for host-specific deoxyribonucleic acid (DNA) markers, fecal coliform bacteria, inorganic and total organic nitrogen, and stable isotopes of nitrate and ammonium.

Samples for quality control were collected for microbiological analyses at a rate of 1 per 20 environmental samples. A total of 14 blank and 15 replicate samples were collected for DNA markers, 52 sequential field replicates were analyzed by the Public Environmental Health Laboratory of the Suffolk County Department of Health Services and the New York State Department of Conservation Marine Laboratory for fecal coliform, and 7 blank and 7 replicate samples were collected to be analyzed for nutrients. Results from qualitycontrol samples collected throughout the course of the study confirmed that sampling procedures were adequate and did not disqualify any data from analysis.
\end{abstract}

\section{Introduction}

The U.S. Geological Survey (USGS) collaborated with the New York State Department of Environmental Conservation (DEC) to assess the potential sources of fecal contamination in seven embayments on Long Island, New York, from June 2018 to July 2019. Water samples are routinely collected by the DEC in Long Island embayments and analyzed for fecal coliform bacteria (FC), an indicator of fecal contamination, to determine if shellfish beds should be closed for harvest and consumption. Fecal indicator bacteria, such as $\mathrm{FC}$, indicate the potential for pathogenic (disease-causing) bacteria to be present. However, the presence of indicator bacteria cannot determine the biological or geographical sources of contamination; microbial source tracking (MST) is used to determine these sources of contamination. MST laboratory techniques can ascertain whether genetic material obtained from Bacteroides or Helicobacter bacteria in water or sediment is consistent with humans, canines (dogs), ruminants (deer, sheep), or waterfowl. Bacteroides and Helicobacter are genera of bacteria found in the gut of most warm-blooded animals. These techniques can also quantify the concentrations of genetic markers found.

The objective of this study was to identify the different pathogen sources, both the host organism (such as human, other mammals, or birds) and geographic origin (such as urban and storm runoff, submarine groundwater discharge), to FC contaminated embayments. The embayment areas selected represent a mix of sewered and unsewered areas, differing levels of impervious land cover, varying population densities, and a variety of land-use types to indicate transferability of $\mathrm{FC}$ to other areas. In total, 353 samples were collected in the seven embayments on Long Island. These were primarily surfacewater samples, but also included 17 groundwater, 11 sediment, 8 fecal, and 2 sewage-treatment plant influent samples. This report presents the approach and methodology (including quality-assurance procedures) used at all seven embayments.

\section{Site Descriptions}

The seven embayments studied include Hempstead Harbor, the Port Jefferson Harbor complex, South Oyster Bay, Nicoll Bay, Patchogue and Bellport Bays, Sag Harbor complex, and Lake Montauk (fig. 1). Hempstead Harbor and South Oyster Bay are in Nassau County on the northern and southern shores of Long Island, respectively, on Long Island Sound and Great South Bay, respectively. The Port Jefferson Harbor complex (encompassing Port Jefferson Harbor, Setauket Harbor, and Conscience Bay) is on the northern shore of Suffolk County on Long Island Sound, and Nicoll Bay and Patchogue 


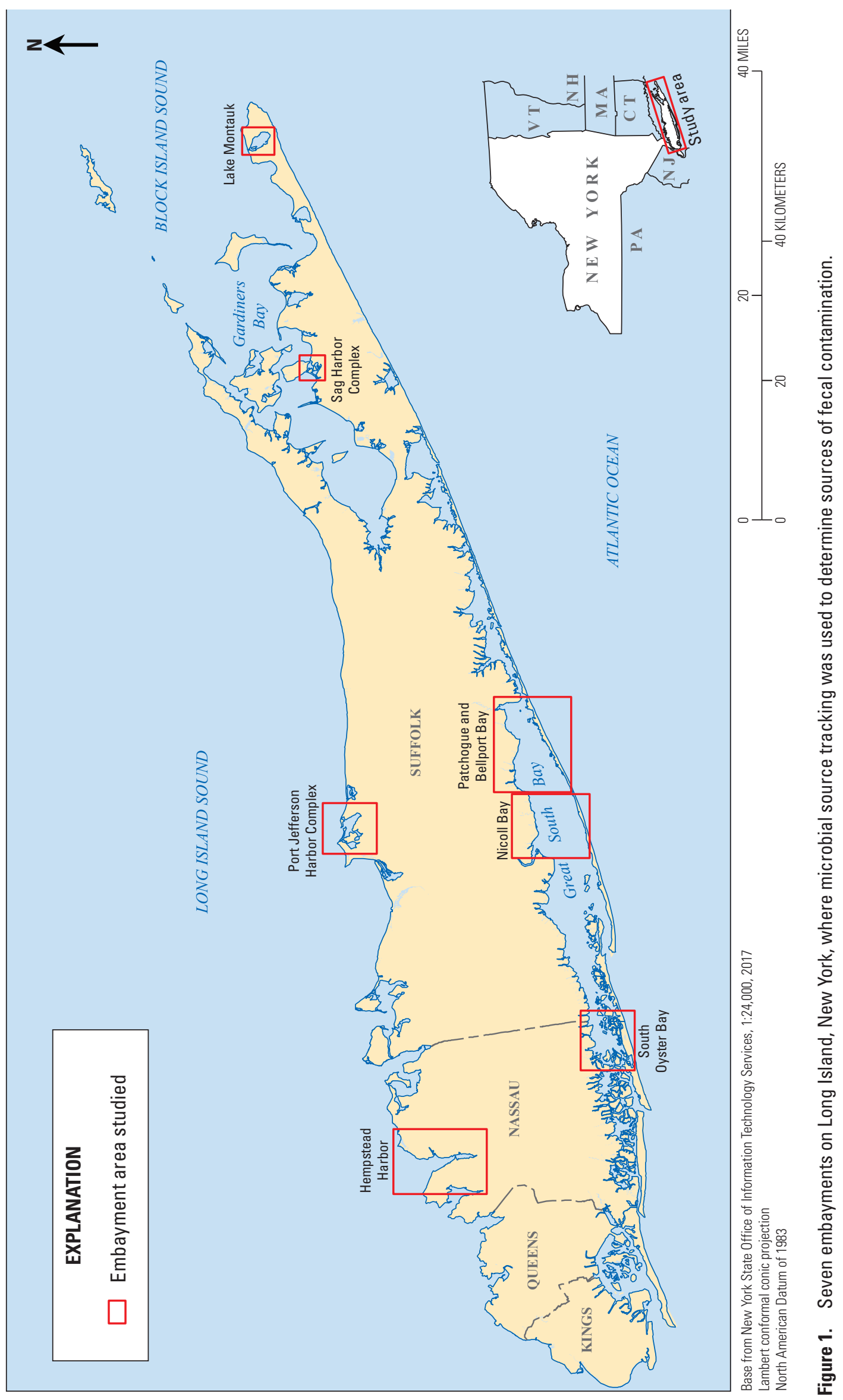


and Bellport Bays are embayments of the Great South Bay on the southern shore of Suffolk County and exchange water with the Atlantic Ocean. The Sag Harbor complex (encompassing several interconnected coves) is on the northern shore of the south fork of Long Island in Suffolk County and exchanges water with Gardiners Bay. Lake Montauk is also on the northern shore of the south fork of Long Island in Suffolk County and exchanges water with Block Island Sound.

\section{Approach and Methods}

MST is a method used to better understand the contributions of fecal contamination, particularly from nonpoint sources, once a problem is identified. MST protocols followed by the USGS typically include several microbiological targets or source identifiers, detection methods, and analytical approaches to link data from water samples to the fecal sources, depending on the objectives of the study (Stoeckel, 2005). In this study, bacterial indicators were used to inform the contribution and the host source of fecal contamination. However, concentrations of the different MST markers cannot be directly compared with each other, and correlation with FC concentrations does not show that these bacteria are necessarily associated with the hosts observed (Roslev and Bukh, 2011).

\section{Sampling Methods}

All samples and field data were collected in accordance with the National Field Manual (U.S. Geological Survey, variously dated). All environmental water-quality data collected in the field and those analyzed in the laboratories as part of this study are available from the USGS National Water Information System (NWIS) database (U.S. Geological Survey, 2020b). Throughout the year, samples were collected a maximum of four times to capture a sample during each season (summer and winter) and each condition type (wet and dry). Wet conditions were defined as more than 0.25 inch of precipitation in 24 hours, as measured by the closest airport, university, or USGS weather station, or 0.50 inch in 48 hours. Dry conditions were defined as less than 0.25 inch of precipitation in 72 hours. For the seven embayments studied, summer samples are considered those collected from June 2018 to September 2018, and winter samples are considered those collected from February 2019 to early May 2019. Sites were differentiated between source (waters flowing directly into the embayment from the land through culverts and groundwater discharge) and receptor (the embayment itself) sites. Groundwater sediment samples were collected irrespective of season or weather conditions; sample collection was in November 2018 and from May 2019 through July 2019.

\section{Laboratory Methods}

Laboratory methods for host-specific deoxyribonucleic acid (DNA) markers, inorganic and total organic nitrogen, and stable isotopes of nitrate and ammonium are detailed in Fisher and others (2020). Samples for fecal coliforms were analyzed at the Suffolk County Department of Health Services Public Environmental Health Laboratory (PEHL) and the DEC Marine Laboratory using standard methods (SM 9221E; Standard Methods for the Examination of Water and Wastewater, 2006) for recreational safety and public health. Each laboratory used different mediums described in the SM 9221E method for the analysis of fecal coliforms; the EC Medium was used by the PEHL and the A-1 Medium was used by the DEC Marine Laboratory. The method reporting limits used for fecal coliform were 20 and 3 most probable number per 100 milliliters (MPN/100 mL) at the PEHL and DEC Marine Laboratory, respectively. PEHL FC data are presented for comparability; FC data analyzed by the DEC are included where available and necessary to fill in data gaps.

\section{Quality Assurance and Quality Control Results}

Quality-control samples, including field blanks and replicate samples, were collected for DNA markers, FC, and nutrients. Additionally, 52 FC samples collected as sequential replicates were split and analyzed by the PEHL and the DEC Marine Laboratory.

\section{Microbial Quality Assurance and Quality Control}

Quality-control samples were collected for microbiological analyses at a rate of 1 per 20 environmental samples. For the entire study, 14 blanks and 15 replicates were collected for MST, a total of 52 sequential field replicates were analyzed by both the PEHL and DEC Marine Laboratory for FC, and 7 blanks and 7 replicates were collected for nutrients to satisfy quality assurance requirements. Known-source fecal samples were collected from dog (one sample), deer (two samples), goose (three samples), and the Sag Harbor sewage-treatment plant influent (human source; two samples).

\section{Blanks}

Results from quality-control samples collected throughout the course of the study confirm that sampling procedures were adequate and did not disqualify any data from analysis. Results with values less than reporting limits (nondetects) were reported for the 14 microbiological blank samples, including 11 field blanks and 3 equipment blanks, for all markers and fecal coliform (table 1). Reporting limits were established by the USGS Ohio Microbiology Laboratory for each 
Table 1. Sample results for quality-assurance blank samples collected at seven embayments on Long Island, New York, from 2018 to 2019.

[USGS, U.S. Geological Survey; ID, identification number; EST, Eastern standard time; HF183, human-associated Bacteroides marker (Seurinck and others, 2005); GFD, waterfowl-associated Helicobacter marker (Green and others, 2012); BacCan, canine-associated Bacteroides marker (Kildare and others, 2007); Rum2Bac, ruminant-associated Bacteroides marker (Mieszkin and others, 2010); copies/100 mL, copies of genetic markers per $100 \mathrm{milliliters;} \mathrm{MPN/100} \mathrm{mL,}$ most probable number per 100 milliliters; ND, no data available; $<$, less than reporting limit; reporting limit established per assay as the lowest concentration detected with 95 percent confidence and established by the USGS Ohio Microbiology Laboratory]

\begin{tabular}{|c|c|c|c|c|c|c|c|c|}
\hline USGS station ID & Date & $\begin{array}{l}\text { Time } \\
\text { (EST) }\end{array}$ & Blank type & $\begin{array}{c}\text { HF183 } \\
\text { (copies/ } \\
100 \mathrm{~mL} \text { ) }\end{array}$ & $\begin{array}{c}\text { GFD } \\
\text { (copies/ } \\
100 \mathrm{~mL} \text { ) }\end{array}$ & $\begin{array}{l}\text { BacCan } \\
\text { (copies/ } \\
100 \mathrm{~mL} \text { ) }\end{array}$ & $\begin{array}{c}\text { Rum2Bac } \\
\text { (copies/ } \\
100 \mathrm{~mL} \text { ) }\end{array}$ & $\begin{array}{c}\text { Fecal } \\
\text { coliform } \\
\text { (MPN/100mL) }\end{array}$ \\
\hline 405000073000016 & $6 / 7 / 2018$ & $11: 40$ & Equipment & $<220$ & $<540$ & $<780$ & $<1,900$ & $<20$ \\
\hline 405005073393301 & $6 / 18 / 2018$ & $12: 16$ & Field & $<1,250$ & $<540$ & $<1,200$ & $<1,880$ & $<20$ \\
\hline 405659073061001 & $7 / 18 / 2018$ & $11: 35$ & Field & $<360$ & $<540$ & $<780$ & $<1,880$ & ND \\
\hline 404409073042201 & $7 / 26 / 2018$ & $9: 55$ & Field & $<360$ & $<540$ & $<780$ & $<1,880$ & $<20$ \\
\hline 404804072530101 & $8 / 20 / 2018$ & $11: 35$ & Field & $<220$ & $<540$ & $<780$ & $<1,900$ & $<20$ \\
\hline 405000073000018 & $11 / 26 / 2018$ & 10:00 & Equipment & $<220$ & $<540$ & $<780$ & $<1,900$ & $<20$ \\
\hline 404604072593801 & $3 / 11 / 2019$ & $9: 50$ & Field & $<220$ & $<540$ & $<780$ & $<1,900$ & $<18$ \\
\hline 404409073042201 & $3 / 18 / 2019$ & 10:03 & Field & $<220$ & $<540$ & $<780$ & $<1,900$ & $<18$ \\
\hline 405637073060601 & 4/1/2019 & $9: 15$ & Field & $<220$ & $<540$ & $<780$ & $<1,900$ & $<18$ \\
\hline 405649073065701 & 4/9/2019 & $9: 27$ & Field & $<260$ & $<650$ & $<940$ & $<2,300$ & $<18$ \\
\hline 404924073385001 & 4/16/2019 & $10: 45$ & Field & $<220$ & $<540$ & $<780$ & $<1,900$ & $<18$ \\
\hline 405649073065701 & $5 / 9 / 2019$ & $5: 50$ & Field & $<260$ & $<650$ & $<940$ & $<2,300$ & $<18$ \\
\hline 404506072525901 & $6 / 3 / 2019$ & $11: 50$ & Field & $<220$ & $<540$ & $<780$ & $<1,900$ & $<18$ \\
\hline 405000073000018 & $6 / 5 / 2019$ & $8: 25$ & Equipment & $<220$ & $<540$ & $<780$ & $<1,900$ & $<18$ \\
\hline
\end{tabular}

assay and defined as the lowest concentration that is detected with 95 percent confidence. Results of the 15 paired replicates varied by microbiological target, and the absolute value log-10 difference (AVLD) was used to compare variability among paired samples with at least one detected value above the reporting limit, as described by Francy and others (2011).

\section{MST Replicates}

For HF183, the AVLD was not determined in six replicate pairs because the marker was not detected in concentrations above the reporting limit in either replicate pair. For six replicate pairs, HF183 was detected in both samples with the AVLD ranging from 0.00 to 0.47 log copy per 100 milliliters (log copies $/ 100 \mathrm{~mL}$ ), which indicates consistency between sample results. In three replicate pairs, one sample has a concentration below the reporting limit and the corresponding sample had a detection, with an AVLD of more than $0.40 \mathrm{log}$ copies $/ 100 \mathrm{~mL}$ being the greatest estimate calculated of these three replicate pairs.

For BacCan, the AVLD was not determined for seven of the 15 replicate pairs. In six replicate pairs where BacCan was detected in concentrations above the reporting limit in both samples of the pair, the AVLD ranged from 0.12 to $1.3 \log$ copies $/ 100 \mathrm{~mL}$, indicating greater variability between replicates than for HF183. In two replicate pairs where one sample was below the reporting limit, the highest AVLD was greater than $0.14 \log$ copies $/ 100 \mathrm{~mL}$.

For GFD, the AVLD was not determined for 9 of the 15 replicate pairs. In one replicate pair, GFD was detected in concentrations above the reporting limit in both samples, with an AVLD of $0.01 \log$ copies $/ 100 \mathrm{~mL}$. In five replicate pairs, one sample had a concentration below the reporting limit, and the corresponding sample had a detection, with an AVLD of greater than $0.63 \mathrm{log}$ copies $/ 100 \mathrm{~mL}$ being the highest of these pairs.

For Rum2Bac, concentrations for all replicate pairs were below the reporting limit and no AVLD was calculated. The AVLD calculated for HF183, BacCan, and GFD were considered satisfactory for the purposes of identifying relative sources in this study.

\section{FC Replicates}

Of the 52 sample replicate sets, the concentrations of $\mathrm{FC}$ were below the reporting limits for both methods in 22 sets. The AVLD for samples with FC concentrations above the reporting limit of both methods ranged from 0.03 to $0.74 \log$ MPN/100 mL. In 19 sample sets, FC concentrations were above the reporting limit by the DEC method but below the reporting limit of the PEHL, with a reporting limit of less 
than $20 \mathrm{MPN} / 100 \mathrm{~mL}$ PEHL and a range of values between 3.6 and $43 \mathrm{MPN} / 100 \mathrm{~mL}$. The concentration of FC in one PEHL analysis was $20 \mathrm{MPN} / 100 \mathrm{~mL}$ compared with less than $3 \mathrm{MPN} / 100 \mathrm{~mL}$ in the DEC analysis. The minor variability between FC results can be attributed to the way in which samples were collected (sequential rather than concurrent) and a slight variation in the analysis method between the two laboratories. For the purposes of this study, interpretation of results between laboratories is comparable.

\section{Source Samples}

Analysis of known-source fecal material resulted in detections of the associated marker in both of the human samples, two of the three Canadian goose samples, and both of the deer samples. With the exception of the dog sample, source samples did not show cross reactivity with the other markers. The fecal material sampled and submitted as a dog sample resulted in a human marker detection rather than a canine marker detection (table 2). What was believed to be a canine sample from the road near the Lake Montauk embayment did not result in detection of the BacCan marker and therefore was possibly not dog but another animal. The USGS Ohio Microbiology Laboratory follows the assay performed in Kildare and others (2007) that has shown that this MST marker successfully identifies canine Bacteroides. MST markers have been shown to not be 100 percent specific, and marker abundances vary among individual hosts (Wang and others, 2010). Additionally, fecal bacteria may be transferred between species living in close contact, obscuring the specificity of the host markers in the sample (Field and Samadpour, 2007; Stewart and others, 2007; Roslev and Bukh, 2011). As for the specific possibility that HF 183 could be detected in a dog fecal sample (if indeed this sample was from a dog), previous studies have indicated false-positive results by HF183-based methods (Shanks and others, 2010; Layton and others, 2013).

\section{Nutrient Quality Assurance and Quality Control}

Two blank samples collected for nutrient analysis had detections of ammonia concentrations close to the reporting limit of less than 0.01 milligrams per liter as nitrogen (mg/L N; table 3) but were still well below concentrations of ammonia detected in environmental samples. Detection of ammonia and organic nitrogen in a blank sample collected on March 11, 2019, indicated contamination in the filtered sample because the unfiltered sample result was less than the detection limit; however, this discrepancy did not affect the results for the analysis of isotopes because submission of isotope samples relied on detectable concentrations of nitrate only. Replicates compared well for all forms of inorganic nitrogen, with the greatest percentage difference of 4.2 percent nitrate plus nitrite in a sample pair measuring 3.49 and $3.64 \mathrm{mg} / \mathrm{L} \mathrm{N}$.

Table 2. Average reported values of Bacteroides and Helicobacter markers from sources studied on Long Island, New York, for microbial source tracking.

[Values in bold typeface indicate samples where the concentration was above the method reporting limit (MRL). The MRL for a given assay is represented by less-than $(<)$ a concentration when a nondetect occurred. The MRL varies per assay and is defined as the lowest concentration detected with 95 percent confidence. EST, Eastern standard time; HF183, human-associated Bacteroides marker (Seurinck and others, 2005); GFD, waterfowl-associated Helicobacter marker (Green and others, 2012); BacCan, canine-associated Bacteroides marker (Kildare and others, 2007); Rum2Bac, ruminant-associated Bacteroides marker (Mieszkin and others, 2010); STP, sewage treatment plant]

\begin{tabular}{|c|c|c|c|c|c|c|}
\hline Date & $\begin{array}{c}\text { Time } \\
\text { (EST) }\end{array}$ & Known source & HF183 & Rum2Bac & GFD & BacCan \\
\hline \multicolumn{7}{|c|}{ Copies per gram dry weight } \\
\hline $6 / 25 / 2018$ & $10: 20$ & Canada goose & $<101,000$ & $<825,000$ & $44,600,000$ & $<357,000$ \\
\hline $7 / 26 / 2018$ & $9: 20$ & Canada goose & $<54,300$ & $<444,000$ & $<133,000$ & $<193,000$ \\
\hline $8 / 7 / 2018$ & $10: 30$ & Duck or goose & $<70,600$ & $<578,000$ & 807,000 & $<250,000$ \\
\hline $8 / 30 / 2018$ & 13:05 & Deer & $<12,600$ & 901,000 & $<31,000$ & $<44,800$ \\
\hline 9/10/2018 & $11: 25$ & Dog & $1,780,000$ & $<382,000$ & $<115,000$ & $<165,000$ \\
\hline $9 / 13 / 2018$ & $10: 45$ & Deer & $<42,700$ & 980,000 & $<105,000$ & $<151,000$ \\
\hline \multicolumn{7}{|c|}{ Copies per 100 milliliters } \\
\hline $6 / 25 / 2018$ & 13:00 & STP influent at Sag Harbor, N.Y. & $1,330,000,000$ & $<301,000$ & $<86,400$ & $24,500,000$ \\
\hline $8 / 13 / 2018$ & $9: 30$ & STP influent at Sag Harbor, N.Y. & $1,790,000,000$ & $<301,000$ & $<86,400$ & $99,000,000$ \\
\hline
\end{tabular}


Table 3. Results from blank samples collected from 2017 to 2019 for various nutrient analyses.

[Method reporting limits (MRLs) for constituents are represented by less than $(<)$ a concentration for a given analyte. Concentrations are in milligrams per liter. EST, Eastern standard time; $\mathrm{NH}_{3}$, ammonia; $\mathrm{NH}_{4}^{+}$, ammonium; ON, organic nitrogen; $\mathrm{NO}_{3}{ }^{-}$, nitrate; $\mathrm{NO}_{2}{ }^{-}$, nitrite; $\mathrm{TN}$, total nitrogen; -, no data available]

\begin{tabular}{|c|c|c|c|c|c|c|c|c|c|c|}
\hline Blank type & Date & $\begin{array}{l}\text { Time } \\
\text { (EST) }\end{array}$ & Ammonia $^{1}$ & $\begin{array}{l}\text { Ammonia } \\
+ \text { organic } \\
\text { nitrogen }^{2}\end{array}$ & $\begin{array}{l}\text { Ammonia } \\
\text { + organic } \text { nitrogen }^{3}\end{array}$ & $\begin{array}{c}\text { Nitrate + } \\
\text { Nitrite }^{4}\end{array}$ & Nitrate $^{5}$ & Nitrite $^{6}$ & $\begin{array}{c}\text { Organic } \\
\text { nitrogen }\end{array}$ & $\begin{array}{c}\text { Total } \\
\text { nitrogen }\end{array}$ \\
\hline Equipment & $11 / 16 / 2017$ & 11:06 & $<0.01$ & - & - & $<0.01$ & $<0.010$ & $<0.001$ & $<0.05$ & - \\
\hline Field & $6 / 12 / 2018$ & $11: 40$ & $<0.01$ & $<0.07$ & $<0.07$ & $<0.040$ & $<0.040$ & $<0.001$ & $<0.07$ & $<0.11$ \\
\hline Equipment & $11 / 26 / 2018$ & $10: 00$ & $<0.01$ & - & - & $<0.040$ & $<0.040$ & $<0.001$ & - & - \\
\hline Equipment & $12 / 6 / 2018$ & $10: 40$ & $<0.01$ & - & - & $<0.01$ & $<0.010$ & $<0.001$ & $<0.05$ & - \\
\hline Field & $3 / 11 / 2019$ & 9:50 & 0.01 & 0.18 & $<0.07$ & $<0.040$ & $<0.040$ & $<0.001$ & $<0.06$ & $<0.11$ \\
\hline Field & 4/9/2019 & 9:27 & 0.02 & $<0.07$ & $<0.07$ & $<0.040$ & $<0.040$ & $<0.001$ & $<0.05$ & $<0.11$ \\
\hline Equipment & $6 / 5 / 2019$ & $8: 25$ & $<0.01$ & - & - & $<0.040$ & $<0.040$ & $<0.001$ & - & - \\
\hline
\end{tabular}

${ }^{1} \mathrm{NH}_{3}+\mathrm{NH}_{4}^{+}$in filtered water; MRL, $<0.01$.

${ }^{2} \mathrm{NH}_{3}+\mathrm{NH}_{4}^{+}+\mathrm{ON}$ in filtered water; MRL, $<0.07$.

${ }^{3} \mathrm{NH}_{3}+\mathrm{NH}_{4}^{+}+\mathrm{ON}$ in unfiltered water; MRL, $<0.07$.

${ }^{4} \mathrm{NO}_{3}{ }^{-}+\mathrm{NO}_{2}{ }^{-}$in filtered water; MRL, $<0.01$ or $<0.040$.

${ }^{5} \mathrm{NO}_{3}{ }^{-}$in filtered water; MRL, $<0.010$ or $<0.040$.

${ }^{6} \mathrm{NO}_{2}{ }^{-}$in filtered water ; MRL, $<0.001$.

${ }^{7} \mathrm{TN}-\mathrm{NO}_{3}{ }^{-}-\mathrm{NO}_{2}{ }^{-}-\mathrm{NH}_{3}-\mathrm{NH}_{4}{ }^{+}$in unfiltered water; $\mathrm{MRL},<0.05,<0.06$, or $<0.07$.

${ }^{8} \mathrm{ON}+\mathrm{NO}_{3}^{-}+\mathrm{NO}_{2}^{-}+\mathrm{NH}_{3}+\mathrm{NH}_{4}^{+}$in unfiltered water; MRL, $<0.11$.

\section{Data Analysis}

The following basis for classifying source sites (with class 1 being the most contaminated) was developed using median $\mathrm{FC}$ ( $\mathrm{FCmed}$ ) concentration and other factors:

- Class $1=F C_{\text {med }}>\left(49+Q_{d w}+C_{s}+C_{c}\right)$

- Class $2=F C_{\text {med }}>\left[49+Q_{d w}+\left(C_{s}\right.\right.$ OR $\left.\left.C_{c}\right)\right]$

- Class $3=F C_{\text {med }}>\left[49+\left(C_{s}\right.\right.$ OR $\left.\left.C_{c}\right)\right]$

- Class $4=F C_{\text {med }}>49$

- Class $5=F C_{\text {med }}<49$

where 49 is $49 \mathrm{MPN} / 100 \mathrm{~mL}$, derived from the 90 -percentile concentration determined by the DEC as part of the National Shellfish Sanitation Program closure criteria (U.S. Food and Drug Administration, 2019); $C_{s}$ is a yes or no value indicating the presence of sewage and is based on any detections of HF 183 concentrations above the reporting limit; $C_{c}$ is a yes or no value indicating the presence of canine waste and is based on any detections of BacCan concentrations above the reporting limit; and $Q_{d w}$ is a yes or no value indicating that high concentrations (above $49 \mathrm{MPN} / 100 \mathrm{~mL}$ ) of FC were detected during dry weather sampling events. Waterfowl and ruminant contributions (that is, detections of GFD and Rum2Bac) were not factored into the classification because their influence is considered natural and not as readily addressed by mitigation.
Additional information was either observed or compiled to facilitate interpretation of data. Precipitation measurements from local rain gages (Weather Underground, 2020) were used to determine dry and wet weather conditions. Quality assurance for rain gage data is unavailable, and values were not used in any quantitative analysis. Relative tide stage as noted by USGS field personnel and verified based on tidal predictions available (National Oceanic and Atmospheric Administration, undated) was documented along with sample information in NWIS (U.S. Geological Survey, 2020b). Geographic information system (GIS) coverages of land cover and sewer districts (Nassau County, 2015; Suffolk County, 2020; U.S. Geological Survey, 2020a) were used to increase confidence in the geographical source of the water and in the likely transport mechanisms of fecal contamination to the embayments studied.

\section{Summary}

The U.S. Geological Survey collaborated with the New York State Department of Environmental Conservation (DEC) to assess the potential sources of fecal contamination in seven embayments on Long Island, New York, from June 2018 to July 2019. Water samples are routinely collected by the DEC and analyzed for fecal coliform bacteria, an indicator of fecal contamination, to determine when shellfish beds should be 
closed to harvest and consumption. Fecal indicator bacteria, such as fecal coliform, signify the potential presence of bacteria that can harm human and animal health.

Indicator bacteria alone cannot determine the biological or geographical sources of contamination. Microbial source tracking (MST) is used to determine these sources of contamination. MST laboratory techniques can ascertain whether genetic material obtained from Bacteroides or Helicobacter bacteria in water or sediment is consistent with humans, canines (dogs), ruminants (deer, sheep), or waterfowl. Bacteroides and Helicobacter are genera of bacteria found in the gut of most warm-blooded animals. These techniques can also quantify the concentrations of genetic markers found.

Information such as the location, weather and season, surrounding land use, and additional water-quality data for the locations where samples are collected help determine the geographical source and conveyance of land-based water to Long Island embayments. The presence of genetic material and fecal coliform in samples collected at the same time is important to show that the fecal coliform is likely from the host source detected. For waters where waste has influenced water quality, it is possible to have genetic material present but no fecal indicators, such as disinfected water from a wastewater treatment plant or from groundwater that has passed through a sandy aquifer.

Water samples for MST on Long Island were collected from source sites (groundwater, stormwater diversions, outfalls, creeks, marinas) and receptor sites (the embayment itself) in the summer and winter seasons. In each of the two seasons, one sample was collected in dry weather, and one, after substantial rainfall. Groundwater sediment samples were also collected throughout the study.

Sites were assessed for fecal contamination to assist stakeholders and resource managers in prioritizing which source sites are consistently contributing fecal coliforms to water bodies on Long Island throughout the year. Classification formula were developed that considered conditions such as high fecal coliform concentrations (particularly in dry weather samples) and contributions from human and canine waste based on detection of MST markers to assist resource managers with remediation priorities.

\section{References Cited}

Field, K.G., and Samadpour, M., 2007, Fecal source tracking, the indicator paradigm, and managing water quality: Water Research, v. 41, no. 16, p. 3517-3538, accessed December 15, 2020, at https://doi.org/10.1016/ j.watres.2007.06.056.
Fisher, S.C., McCarthy, B.A., Kephart, C.M., and Griffin, D.W., 2020, Assessment of water quality and fecal contamination sources at Hook Pond, East Hampton, New York: U.S. Geological Survey Scientific Investigations Report 2020-5071, 58 p., accessed December 15, 2020, at https://doi.org/10.3133/sir20205071.

Francy, D.S., Stelzer, E.A., Bushon, R.N., Brady, A.M.G., Mailot, B.E., Spencer, S.K., Borchardt, M.A., Elber, A.G., Riddell, K.R., and Gellner, T.M., 2011, Quantifying viruses and bacteria in wastewater-Results, interpretation methods, and quality control: U.S. Geological Survey Scientific Investigations Report 2011-5150, 44 p., accessed December 15, 2020, at https://doi.org/10.3133/sir20115150.

Green, H.C., Dick, L.K., Gilpin, B., Samadpour, M., and Field, K.G., 2012, Genetic markers for rapid PCRbased identification of gull, Canada goose, duck, and chicken fecal contamination in water: Applied and Environmental Microbiology, v. 78, no. 2, p. 503-510, accessed December 15, 2020, at https://doi.org/10.1128/ AEM.05734-11.

Kildare, B.J., Leutenegger, C.M., McSwain, B.S., Bambic, D.G., Rajal, V.B., and Wuertz, S., 2007, 16S rRNA-based assays for quantitative detection of universal, human-, cow-, and dog-specific fecal Bacteroidales-A Bayesian approach: Water Research, v. 41, no. 16, p. 3701-3715, accessed December 15, 2020, at https://doi.org/10.1016/ j.watres.2007.06.037.

Layton, B.A., Cao, Y., Ebentier, D.L., Hanley, K., Ballesté, E., Brandāo, J., Byappanahalli, M., Converse, R., Farnleitner, A.H., Gentry-Shields, J., Gidley, M.L., Gourmelon, M., Lee, C.S., Lee, J., Lozach, S., Madi, T., Meijer, W.G., Noble, R., Peed, L., Reischer, G.H., Rodrigues, R., Rose, J.B., Schriewer, A., Sinigalliano, C., Srinivasan, S., Stewart, J., Van De Werfhorst, L., Wang, D., Whitman, R., Wuertz, S., Jay, J., Holden, P.A., Boehm, A.B., Shanks, O., and Griffith, J.F., 2013, Performance of human fecal anaerobe-associated PCR-based assays in a multi-laboratory method evaluation study: Water Research, v. 47, no. 18, p. 6897-6908, accessed December 15, 2020, at https://doi.org/10.1016/ j.watres.2013.05.060.

Mieszkin, S., Yala, J.-F., Joubrel, R., and Gourmelon, M., 2010, Phylogenetic analysis of Bacteroidales 16S rRNA gene sequences from human and animal effluents and assessment of ruminant faecal pollution by real-time PCR: Applied Microbiology, v. 108, no. 3, p. 974-984, accessed March 30, 2021, at https://doi.org/10.1111/j.13652672.2009.04499.x.

Nassau County, 2015, Nassau County DPW sanitary sewer collection districts: Nassau County data, accessed March 30, 2021, at https://www.arcgis.com/home/item.html?id=26 d010a660d047c495d2226df26af81a 
National Oceanic and Atmospheric Administration, [undated], Tides and currents: National Oceanic and Atmospheric Administration tide predictions web page, accessed March 1, 2021, at https://tidesandcurrents.noaa.gov/tide_ predictions.html.

Roslev, P., and Bukh, A.S., 2011, State of the art molecular markers for fecal pollution source tracking in water: Applied Microbiology and Biotechnology, v. 89, no. 5, p. 1341-1355, accessed December 15, 2020, at https://doi.org/10.1007/s00253-010-3080-7.

Seurinck, S., Defoirdt, T., Verstraete, W., and Siciliano, S.D., 2005, Detection and quantification of the human-specific HF183 Bacteroides 16S rRNA genetic marker with realtime PCR for assessment of human faecal pollution in freshwater: Environmental Microbiology, v. 7, no. 2, p. 249-259, accessed March 30, 2021, at https://doi.org/10.1111/j.14622920.2004.00702.x.

Shanks, O.C., White, K., Kelty, C.A., Sivaganesan, M., Blannon, J., Meckes, M., Varma, M., and Haugland, R.A., 2010, Performance of PCR-based assays targeting Bacteroidales genetic markers of human fecal pollution in sewage and fecal samples: Environmental Science \& Technology, v. 44, no. 16, p. 6281-6288, accessed June 23, 2020, at https://doi.org/10.1021/es100311n.

Standard Methods for the Examination of Water and Wastewater, 2006, Fecal coliform procedure, sec. 9221E of Multiple-tube fermentation technique for members of the coliform group: Standard Methods For the Examination of Water and Wastewater, p. 9-10, accessed March 19, 2020, at http://edgeanalytical.com/wp-content/uploads/Micro SM9221.pdf. [Also available at https://www.standardme thods.org/doi/abs/10.2105/SMWW.2882.192.]

Stewart, J.R., Santo Domingo, J.W., and Wade, T.J., 2007, Fecal pollution, public health, and microbial source tracking, in Santo Domingo, J.W., and Sadowsky, M.J., eds., Microbial source tracking: Washington, D.C., ASM Press, p. 1-32. [Also available at https://doi.org/10.1128/ 9781555815769.ch1.]
Stoeckel, D.M., 2005, Selection and application of microbial source tracking tools for water-quality investigations: U.S. Geological Survey Techniques and Methods, book 2, chap. A3, 43 p., accessed December 15, 2020, at https://doi.org/10.3133/tm2A3.

Suffolk County, 2020, GIS viewer-Suffolk County: Suffolk County data, accessed March 30, 2021, at https:/gisportal. suffolkcountyny.gov/gis/home/.

U.S. Food and Drug Administration, 2019, National shellfish sanitation program - Guide for the control of molluscan shellfish-2019 revision: U.S. Food and Drug Administration, 502 p., accessed March 1, 2021, at https:/www.fda.gov/food/federalstate-food-programs/ national-shellfish-sanitation-program-nssp.

U.S. Geological Survey, 2020a, National land cover database: U.S. Geological Survey data, accessed December 15, 2020, at https://www.usgs.gov/centers/eros/science/nationalland-cover-database?qt-science_center_objects $=0 \#$ qtscience_center_objects.

U.S. Geological Survey, 2020b, USGS water data for the nation: U.S. Geological Survey National Water Information System database, accessed July 31, 2020, at https://doi.org/ 10.5066/F7P55KJN.

U.S. Geological Survey, [variously dated], The national field manual for the collection of water-quality data: U.S. Geological Survey Techniques and Method, book 9, chaps. A1-A9, [variously paged], accessed June 23, 2020, at https://water.usgs.gov/owq/FieldManual/.

Wang, D., Silkie, S.S., Nelson, K.L., and Wuertz, S., 2010, Estimating true human and animal host source contribution in quantitative microbial source tracking using the Monte Carlo method: Water Research, v. 44, no. 16, p. 4760-4775, accessed December 12, 2020, at https://doi.org/10.1016/ j.watres.2010.07.076.

Weather Underground, 2020, Daily precipitation: Weather Underground maps catalog, accessed January 12, 2021, at https:/www.wunderground.com/maps/precipitation/daily. 
For more information, contact:

Director, New York Water Science Center

U.S. Geological Survey

425 Jordan Road

Troy, NY 12180-8349

dc_ny@usgs.gov

or visit our website at

https://www.usgs.gov/centers/ny-water

Publishing support provided by the

Pembroke Publishing Service Center 


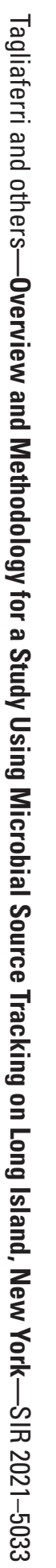

